\title{
PENINGKATAN KAPASITAS PRODUKSI MELALUI REKONSTRUKSI DAN PEMBANGUNAN RUMAH ASAP IKAN PATIN DI UMKM PUTRA NIAGA KABUPATEN KAMPAR
}

\author{
Dewi Fortuna Ayu ${ }^{1 *}$, Andarini Diharmi ${ }^{2}$, Evy Rossi ${ }^{1}$, Syahrul $^{2}$ \\ ${ }^{1}$ Jurusan Teknologi Pertanian, Fakultas Pertanian, Universitas Riau, Pekanbaru, Indonesia \\ ${ }^{2}$ Jurusan Teknologi Hasil Perikanan, Fakultas Perikanan dan Ilmu Kelautan, Universitas Riau, Pekanbaru, \\ Indonesia \\ * Penulis Korespodensi : Fortuna_ayu2004@yahoo.com
}

\begin{abstract}
Abstrak
Usaha Mikro Kecil Menengah Putra Niaga di Desa Lubuk Agung Kabupaten Kampar Provinsi Riau dinilai layak dikembangkan sebagai penghasil produk unggulan daerah Riau karena memiliki karyawan tetap 8 orang dengan omzet Rp. 48.000.000,-/bulan, serta pemasaran yang mencapai Malaysia pada tahun 2015 dan 2016. Namun, akibat kapasitas rumah asap yang terbatas menyebabkan produksi ikan asap belum mampu memenuhi kebutuhan pasar ekspor maupun dalam negeri yang masih terbuka luas. Kegiatan pengabdian kepada masyarakat ini bertujuan untuk meningkatkan kapasitas produksi melalui rekonstruksi dan pembangunan ulang rumah asap. Rumah asap lama berukuran $3 \times 1.8 \mathrm{~m}$ terdiri dari 3 ruang asap dengan dinding dan atap seng direkonstruksi dan dibangun ulang menjadi $7 \times 6 \mathrm{~m}$ dengan 5 ruang asap yang lebih modern. Penggunaan rumah asap baru menunjukkan terjadinya peningkatan kapasitas produksi dari $500 \mathrm{~kg}$ menjadi $800 \mathrm{~kg}$ ikan per produksi. Ikan asap yang dihasilkan menunjukkan rasa enak, bau, dan warna coklat khas ikan asap. Ikan asap ini memiliki kadar air dan lemak yang hampir sama masing-masing sebesar $32.92 \%$ dan 32.85 , serta $4,35 \%$ dan $4.25 \%$. Kadar air dan kadar lemak ini sudah memenuhi standar mutu ikan asap dengan pengasapan panas (SNI 2725:2013).
\end{abstract}

Kata kunci: Ikan Patin, Rumah Asap, Rekonstruksi, UMKM.

\begin{abstract}
Small Micro Enterprises Scale Putra Niaga in Lubuk Agung Village Kampar District Riau Province is considered well-developed as a producer of Riau superior local products because it has permanent employees of 8 persons with a turnover of Rp. 48.000.000,--/month, as well as marketing that reached Malaysia in 2015 and 2016. However, due to limited capacity of smoke house, the production has not been able to meet the needs of export and domestic market which is still widely open. This community service aims to increase the production capacity through reconstruction and rebuilding of the smoke house. The old smoke house size of $3 x 1.8 \mathrm{~m}$ consists of 3 smoke rooms with wall and constructed zinc roof and rebuilt into $7 x 6 \mathrm{~m}$ with 5 modern smoke rooms. The use of new smoke house showed an increase in production capacity from 500 to $800 \mathrm{~kg}$ of fish per production. The resulting smoked fish showed taste, smell, and brown color typical of smoked fish. These smoked fish has almost equal water and fat content, such as $32.92 \%$ and $32.85 \%$, as well as $4.35 \%$ and $4.25 \%$, respectively. These moisture and fat content has been meeting the quality standards of smoked fish with heat smoking (SNI 2725:2013).
\end{abstract}

Keywords: Patin fish, Smoke House, Reconstruction, SMES.

\section{PENDAHULUAN}

Ikan patin (Pangasius hypothalamus) merupakan salah satu komoditas utama budidaya perikanan di Provinsi Riau. Produksi ikan patin di Provinsi Riau pada tahun 2014 telah mencapai $1.602,90$ ton, mengalami peningkatan sebanyak 2.3 ton pada tahun 2015 menjadi 1.605,2 ton (BPS, 2015). Kabupaten Kampar merupakan salah satu dari lima kabupaten di Provinsi Riau yang ditetapkan sebagai Kawasan Minapolitan berdasarkan Keputusan Menteri Kelautan dan Perikanan Nomor 35/KEPMEN-KP/2013 tentang Penetapan Kawasan Minapolitan. Kawasan Minapolitan di Kabupaten Kampar berlokasi di
Kecamatan XIII Koto Kampar dengan komoditas utamanya adalah ikan patin (Tibrani, 2015).

Pengembangan ikan patin yang telah dilakukan di Kabupaten Kampar terutama di Desa Lubuk Agung tidak hanya mencakup aspek budidaya saja, tetapi sudah dikembangkan sampai ke aspek pengolahannya. Masyarakat Desa Lubuk Agung umumnya mengolah ikan patin dengan cara pengasapan atau yang lebih dikenal dengan nama ikan salai. Ikan asap adalah ikan segar yang mengalami perlakuan penyiangan, pencucian dengan atau tanpa perendamaan dalam larutan garam, penirisan, dengan atau tanpa pemberian rempah dan pengasapan panas yang dilakukan dalam 
ruang pengasapan dengan menggunakan kayu, sabut, atau tempurung kelapa (BSN, 2013). Menurut Rodiah et al., (2016), ikan patin segar yang diolah menjadi ikan asap di Kabupaten Kampar sebanyak 10-15 ton/hari akan menghasilkan ikan asap sebanyak 5-7 ton/hari.

Salah satu UMKM yang berkembang di Kabupaten Kampar adalah UMKM Putra Niaga yang telah berdiri sejak tahun 2007. UMKM Putra Niaga didirikan oleh Firman Edy menggunakan modal kekayaan pribadi dengan memanfaatkan pasokan ikan patin jenis siam yang banyak dibudidayakan di Kabupaten Kampar. Ikan patin yang digunakan sebagai bahan baku ikan asap berusia 3,5 bulan dengan berat $250-300 \mathrm{~kg} /$ ekor untuk mendapatkan berat produk yang seragam. Ikan patin ini dipanen pada pagi hari kemudian langsung disiangi untuk melalui proses pengasapan selanjutnya. Daging ikan patin merupakan sumber protein tinggi sebesar $16 \%$ dan mengandung kadar lemak tinggi sehinggga mudah mengalami oksidasi jika tidak segera diolah (Hastarini, 2012). Proses pengolahan ikan asap hanya memanfaatkan daging ikan, sedangkan limbah berupa isi perut hanya dibuang sebagai limbah. Menurut Hastarini et al., (2012), limbah isi perut ikan patin yang terhitung $10,8 \pm 0,16 \%$ dapat dimanfaatkan sebagai sumber minyak ikan dengan rendemen sebesar 35,32\%, sedangkan menurut Ayu et al. (2019), proses pemurnian lemak abdomen ikan patin menghasilkan rendemen minyak ikan patin murni sebesar $78,14 \%-87,45 \%$

Proses produksi ikan patin asap di UMKM Putra Niaga meliputi penyiangan, pencucuian, dan penirisan ikan, pengasapan, pengemasan, dan pemasaran langsung ke pasar atau melalui pemesanan dalam jumlah besar. Proses produksi ikan asap ini masih menggunakan peralatan sederhanan dan rumah asap tradisional. Proses pengasapan dilakukan dalam 2 tahapan, yaitu pengasapan untuk menghilangan kadar air dan minyak, masing-masing selama 8 jam. Penggunaan rumah asap tradisional ini dinilai belum efisien karena selain kapasitas produksi yang terbatas, suhu pengasapan tidak maksimal dan belum konsisten akibat asap menyebar, sehingga banyak menghabiskan kayu bakar sebagai bahan bakar serta produk tidak tahan lama (kadar air dan kadar lemak yang tinggi). Hal ini berdampak pada kesulitan pemasaran ikan asap terutama ke daerah yang jauh dengan jumlah yang lebih besar.

UMKM Putra Niaga hanya memiliki 2 dapur dan 3 rumah tungku asap tradisional dengan nilai investasi sekitar Rp. 300.000.000,-. Dengan kondisi peralatan dan fasilitas sarana dan prasana yang sederhana, UMKM Putra Niaga mampu memproduksi rata-rata 2 ton ikan salai/minggu, dengan harga jual Rp. 60.000,$/ \mathrm{kg}$, sehingga UMKM ini memiliki omzet Rp. 48.000.000,- /bulan atau Rp. 576.000.000,-/tahun. Satu kali produksi UMKM Putra Niaga membutuhkan $500 \mathrm{~kg}$ ikan patin segar dan dalam 1 minggu hanya mampu melakukan 2 kali proses produksi. Ikan asap yang diproduksi memiliki rendemen sebesar 30\% dari bahan baku yang digunakan.

Walaupun diproduksi dengan cara tradisional dan dipasarkan secara sederhana, produk ikan asap merupakan salah satu produk unggulan daerah Provinsi Riau. Ikan asap selain dikonsumsi sebagai lauk pauk juga dikenal sebagai oleh-oleh khas Riau. Produk ikan asap sendiri sudah banyak dijual di gerai-gerai makanan khas Riau dengan kemasan dan mutu yang baik. Namun untuk produk ikan asap UMKM Putra Niaga belum pernah dijual di gerai-gerai makanan khas Riau. Pemasaran ikan asap UMKM Putra Niaga sudah dilakukan hingga ke Pekanbaru, Sumatera Barat, Batam, bahkan pada tahun 2015 dan 2016 pernah diekspor ke Malaysia. Namun, berhubung kapasitas produksi yang belum memadai dan mutu produk yang terbatas, eskspor ke luar negeri terhenti guna mempriorotaskan pemenuhan kebutuhan pasar dalam negeri. Oleh karena itu, kegitan ini bertujuan untuk meningkatkan kapasitas produksi ikan asap melalui rekonstruksi dan pembangunan rumah asap di UMKM Putra Niaga Kabupatean Kampar Provinsi Riau.

\section{METODE PELAKSANAAN KEGIATAN PEMBERDAYAAN MASYARAKAT}

\subsection{Waktu dan Tempat}

Kegiatan pengabdian kepada masyarakat dilakukan di UMKM Putra Niaga yang berlokasi di Desa Lubuk Agung, Kecamatan XIII Koto Kampar, Kabupaten Kampar, Provinsi Riau. Kegiatan ini dilakukan selama 6 bulan, mulai Bulan Maret hingga September 2019.

\subsection{Metode Pendekatan}

Kegiatan pengabdian kepada masyarakat diawali dengan survey lokasi dan penjajakan kerjasama dengan mitra yang kemudian ditindaklanjuti dengan sosialisasi rencana kegiatan kepada mitra serta pernyataan kesediaan mitra untuk ikut berpartisipasi selama kegiatan berlangsung. Kegiatan ini dilakukan dalam 3 tahapan, yaitu (1) diskusi dan perencanaan desain rumah asap, (2) rekonstruksi dan pembangunan rumah asap, dan (3) evaluasi penggunaan rumah asap.

\section{HASIL DAN PEMBAHASAN}

\subsection{Diskusi perencanaan desain rumah asap}

Usaha Mikro Kecil Menengah Putra Niaga merupakan salah satu penghasil ikan patin asap yang cukup dikenal di Desa Lubuk Agung Kabupaten Kampar Provinsi Riau. Survey lokasi dan penjajakan kerjasama dengan mitra telah dilakukan sejak bulan Oktober 2018. Kegiatan ini diawali dengan kerjasama dalam kegiatan penelitian antara tim dengan mitra guna memanfaatkan limbah lemak abdomen ikan patin (Diharmi et al., 2018). Kerjasama ini kemudian berlanjut menjadi kegiatan pengabdian kepada masyarakat. Usaha Mikro Kecil Menengah Putra Niaga dinyatakan layak sebagai mitra kegiatan PPUD tahun 2019 dengan memperhatikan persyaratan dan kriteria yang berlaku. Pimpinan UMKM Putra Niaga, Firman Edy menyatakan kesediaannya untuk 
mengikuti kegiatan PPUD 2019 dengan menandatangani surat pernyaatan kesediaan.

Berdasarkan hasil diskusi tim dengan mitra, hal yang sangat mendesak dan dibutuhkan oleh mitra adalah rumah asap, dimana salah satu diantara tiga rumah asap yang dimiliki oleh mitra hanya berupa kios berukuran $3 \times 1.8 \mathrm{~m}$ yang terdiri dari 3 ruang asap (Gambar 1). Dinding dan atap rumah asap menggunakan seng sehingga asap menyebar, panas tidak merata, ikan asap lambat matang, serta menghabiskan kayu bakar yang lebih banyak. Rata-rata total kayu bakar yang dihabiskan untuk mengasapkan ikan patin sebanyak 2 ton. Kayu bakar ini digunakan sebagai bahan bakar ketiga rumah asap untuk proses pengasapan selama 2 hari. Dampak perbaikan desain rumah asap yang dilakukan diharapkan akan terjadinya peningkatan kapasitas produksi dan perbaikan mutu produk ikan asap.

\subsection{Rekonstruksi dan Pembangunan Rumah Asap}

Kegiatan rekonstruksi dan pembangunan rumah asap dilakukan selama dua bulan, mulai Bulan April hingga Mei 2019. Kegiatan rekonstruksi ini selain dilakukan di lokasi mitra juga dilakukan di Pekanbaru dengan melibatkan anggota tim yang mampu mendisain rumah asap. Salah satu dari ketiga rumah asap tradisional yang dimiliki UMKM Putra Niaga dibongkar dan diganti melalui rekonstruksi rumah asap baru dengan kapasitas dan desain yang lebih modern. Rumah asap yang dibangun ukuran 7x6 m, tinggi bagian depan $4 \mathrm{~m}$ sedangkan tinggi bagian belakang $3 \mathrm{~m}$. Rumah asap ini memiliki 5 ruang asap, dimana masing-masing terdiri dari 7 rak guna menempatkan ikan patin selama proses pengasapan. Rumah asap didesain sedemikan rupa agar asap di tidak menyebar dan ada ruangan di sela-sela atap yang berfungsi untuk mengeluarkan asap secara terpusat. Pada bagian atap bagian depan dibuat semacam poni untuk memudahkan pengeluaran asap. Seluruh tiang rumah asap dicor, dinding dibangun menggunakan bata dan atap dari baja ringan.

Hasil rekonstruksi kemudian ditindak lanjuti dengan kegiatan pembongkaran dan pembangunan rumah asap (Gambar 1). Kegiatan pembongkaran dan pembangunan rumah asap direncanakan berlangsung selama 3 bulan, mulai Bulan Mei hingga Agustus 2019. Mengingat banyaknya permintaan ikan asap selama bulan Ramadhan dan libur hari Raya Idul Fitri, maka pembongkaran rumah asap lama dimulai bulan Juni 2019.

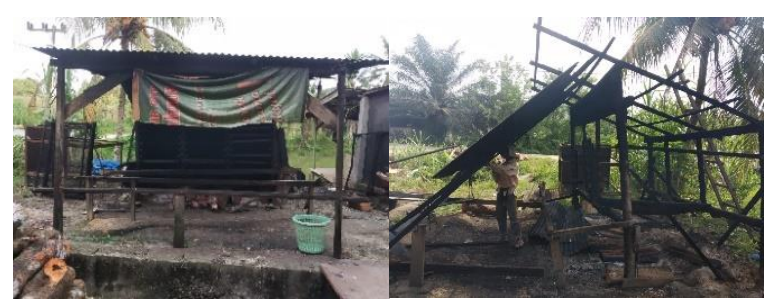

Gamba 1. Pembongkaran rumah asap lama.
Total biaya yang dihabiskan untuk pembelian material bangunan termasuk upah tenaga kerja untuk pembangunan rumah asap sebesar Rp. 65.000.000,Pemesanaan material sebagian besar dilakukan di toko material An-Nur yang berlokasi di Kuok, dan beberapa material yang sulit diperoleh di Kabupaten Kampar seperti besi dan baja ringan (atap) disediakan dari Pekanbaru. Pemesanan dan pembelian pasir cor, kerekel jagung, papan, serta pembayaran upah tenaga kerja yang berasal dari Desa Lubuk Aguk dilakukan oleh mitra, menggunakan dana yang telah disepakati disediakan oleh mitra sebesar Rp. 10.000.000,-.

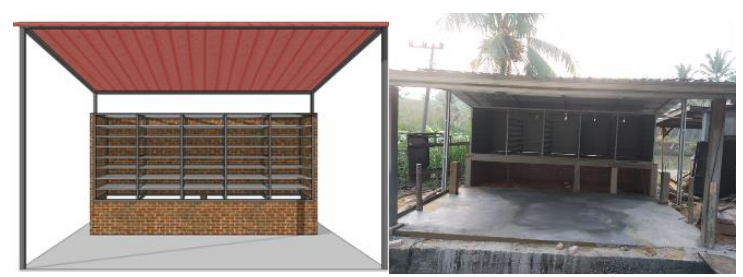

Gambar 2. Desain dan pembangunan rumah asap baru.

Rumah asap yang baru memiliki 5 ruang asap, masingmasing ruang terdiri dari 7 rak lemari asap. Rak-rak lemari asap didisain dan dibuat di Pekanbaru, dikirimkan ke mitra menggunakan truk. Pemasangan rak lemari asap dan atap dilakukan setelah selesai pondasi dan dinding ruangan pengasapan. Penambahan besi plat sebagai penyanggga rak lemari asap juga dilakukan agar lemari asap mampu menahan beban ikan asap hingga 2 ton. Untuk memudahkan memasukkan rak berisi ikan yang akan dikeringkan ke dalam lemari pengering, digunakan tiang dan penyangga sebagai rel. Sebelumnya rumah asap lama menggunakan tiang dan penyangga yang terbuat dari kayu. Akan tetapi karena kayu yang besar dan kuat sulit diperoleh, maka tiang dan penyangga rak rumah asap yang baru terbuat dari besi.

Pemasangan kuda-kuda dan atap merupakan tahap akhir dalam pembangunan rumah asap. Pemasangan kuda-kuda dan atap dilakukan oleh tenaga kerja tukang dari Pekanbaru yang memiliki keahlian memasang kuda-kuda dan atap. Agar tahan lama, atap yang digunakan terbuat dari seng dan kuda-kuda dari baja ringan. Pemasangan kuda-kuda dan atap dilakukan selama seminggu.

\subsection{Evaluasi Penggunaan Rumah Asap}

Hasil percobaan penggunaan rumah asap baru menunjukkan terjadinya peningkatan kapasitas produksi pengasapan ikan. Rumah asap lama yang berukuran $3 \times 1.8 \mathrm{~m}$ dengan 3 ruang asap mampu memproduksi $500 \mathrm{~kg}$ ikan patin per hari melalui $2 \mathrm{kali}$ proses pengasapan. Proses pengasapan tahap pertama dilakukan selama 8 jam untuk mengeringkan air, sedangkan proses pengasapan tahap kedua selama 8 jam untuk mengeringkan minyak.

Penggunaan rumah asap baru berukuruan 7x6 m dengan 5 ruang asap menunjukkan bahwa rumah asap 
ini mampu mengasapkan ikan patin sebanyak $800 \mathrm{~kg}$ per produksi. Proses pengasapan juga membutuhkan waktu yang sama, dilakukan dalam 2 tahapan, tahap pertama selama 8 jam untuk mengeringkan air dan tahap kedua selama 8 jam untuk mengeringkan minyak. Peningkatan kapasitas produksi ini berdampak pada penambahan tenaga kerja untuk menyiangi ikan asap. Tenaga kerja untuk menyiangi ikan pada rumah asap lama sebanyak 5 orang sedangkan pada rumah asap baru sebanyak 7 orang. Jumlah tenaga kerja yang bertugas untuk mengasapkan ikan pada rumah asap masih sebanyak 3 orang karena pekerjaan ini bisa dilakukan secara bergantian.

Berdasarkan hasil pengujian organoleptik yang dilakukan, ikan patin asap yang dihasilkan baik menggunakan rumah asap lama maupun yang baru memiliki karakteristik rasa yang enak, bau dan warna coklat khas ikan asap yang hampir sama. Hasil analisis kimia juga menunjukkan bahwa ikan asap ini memiliki kadar air dan kadar lemak yang hampir sama, masingmasing sebesar $32.92 \%$ dan $32.85 \%$ untuk kadar air dan $4,35 \%$ dan $4.25 \%$ untuk kadar lemak. Kadar air dan kadar lemak ini sudah memenuhi standar mutu ikan asap dengan pengasapan panas (SNI 2725:2013), masing-masing kadar air dan lemak maksimal sebesar $60 \%$ dan $20 \%$. Capaian kegiatan rekonstruksi dan pembangunan rumah asap ikan patin dapat dilihat pada Tabel 1.

Tabel 1. Capaian kegiatan rekonstruksi dan pembangunan rumah asap ikan patin.

\begin{tabular}{|c|c|c|c|}
\hline No. & Kriteria Capaian & $\begin{array}{l}\text { Rumah } \\
\text { Asap } \\
\text { Lama }\end{array}$ & $\begin{array}{l}\text { Rumah } \\
\text { Asap Baru }\end{array}$ \\
\hline 1 & $\begin{array}{l}\text { Kapasitas produksi } \\
\text { (kg ikan/produksi) }\end{array}$ & 500 & 800 \\
\hline 2 & $\begin{array}{l}\text { Tenaga } \\
\text { menyiangi } \\
\text { (orang) }\end{array}$ & 5 & 7 \\
\hline 3 & $\begin{array}{lr}\text { Tenaga } & \text { kerja } \\
\text { mengasapkan } & \text { ikan } \\
\text { (orang) } & \end{array}$ & 3 & 3 \\
\hline 4 & $\begin{array}{l}\text { Karakteristik } \\
\text { organoleptik bau }\end{array}$ & $\begin{array}{l}\text { Khas } \\
\text { ikan asap }\end{array}$ & $\begin{array}{l}\text { Khas } \\
\text { asap }\end{array}$ \\
\hline 5 & $\begin{array}{l}\text { Karakteristik } \\
\text { organoleptik rasa }\end{array}$ & $\begin{array}{l}\text { Enak } \\
\text { khas ikan } \\
\text { asap }\end{array}$ & $\begin{array}{l}\text { Enak khas } \\
\text { ikan asap }\end{array}$ \\
\hline 6 & $\begin{array}{l}\text { Karakteristik } \\
\text { organoleptik warna }\end{array}$ & $\begin{array}{l}\text { Coklat } \\
\text { tua }\end{array}$ & Coklat muda \\
\hline 7 & Kadar air $(\%)$ & $32.92 \%$ & 32.85 \\
\hline 8 & Kadar lemak $(\%)$ & 4.35 & 4.25 \\
\hline
\end{tabular}

Menurut Putra (2017), pengasapan ikan patin dengan metode pengasapan yang berbeda memberikan pengaruh nyata terhadap karakteristik organoleptik, kadar air, kadar lemak, bilangan peroksida, dan uji jamur. Metode pengasapan tradisional memberikan karakteristik mutu ikan asap yang lebih baik dibandingkan metode asap cair dengan nilai organoleptik rupa $(8,71)$, bau $(8,62)$, rasa $(7,85)$, tekstur $(7,77)$, dan kadar air $(32,52 \%)$, kadar lemak $(4,35 \%)$, bilangan peroksida $(0,03 \mathrm{meq} / \mathrm{g})$, serta uji jamur negatif.

\section{KESIMPULAN}

Kegiatan rekonstruksi dan pembangunan rumah asap di UMKM Putra Niaga telah menunjukkan terjadinya peningkatan kapasitas produksi dari $500 \mathrm{~kg}$ menjadi $800 \mathrm{~kg}$ ikan patin per produksi. Hasil pengujian mutu ikan asap menunjukkan rasa yang enak, bau, dan warna khas ikan asap. Ikan asap ini memiliki kadar air dan lemak yang hampir sama dengan kadar air dan lemak ikan asap yang menggunakan rumah asap lama. Kadar air dan kadar lemak ini sudah memenuhi standar mutu ikan asap dengan pengasapan panas (SNI 2725:2013).

\section{UCAPAN TERIMA KASIH}

Ucapan terima kasih disampaikan kepada Direktorat Riset dan Pengabdian Kepada Masyarakat Kemenristekdikti dan Lembaga Penelitian dan Pengabdian kepada Masyarakat Universitas Riau yang telah membiayai kegiatan ini melalui Program Pengembangan Unggulan Daerah tahun 2019 dengan nomor kontrak 530/UN.19.5.1.3/PT.01.03/2019. Ucapan terima kasih juga disampaikan kepada Bapak Firman Edy selaku pemilik UMKM Putra Niaga dan pihak-pihak yang membantu pelaksanaan kegiatan ini.

\section{DAFTAR PUSTAKA}

Ayu, D.F, Diharmi, A. \& Ali, A. (2019). Karakteristik fisiko-kimia dan komposisi asam lemak minyak ikan dari lemak abdomen limbah pengasapan ikan patin (Pangasius hypothalamus). Jurnal Pengolahan Hasil Perikanan Indonesia, 22(1), 187-197.

BPS Riau. (2015). Riau dalam Angka 2015. Badan Pusat Statistik Provinsi Riau. Riau.

BSN. (2013). SNI 2725 Ikan Asap dengan Pengasapan Panas. Badan Standardisasi Nasional..

Diharmi, A., Ayu, D.F. \& Herawati, N. (2018). Peranan Komposisi Asam Lemak, BetaKaroten, Tokoferol, dan Klorofil, terhadap Stabilitas Foto-Oksidasi Produk Emulsi Campuran Minyak Ikan Patin dan Minyak Sawit Merah. Laporan Akhir Hibah Skema Penelitian Unggulan tahun 2018. Universitas Riau.

Hastarini, E. (2012). Karakteristik minyak ikan dari limbah pengolahan filet ikan patin siam (Pangasius hypopthalmus) dan patin jambal (Pangasius djambal). Disertasi. Institut Pertanian Bogor.

Hastarini, E., Fardiaz, D., Irianto, H. E \& Budijanto, S. (2012). Karakteristik minyak ikan dari limbah pengolahan filet ikan patin siam (Pangasius hypothalmus) dan patin jambal (Pangasius djambal). Agritech 32(4), 403-410.

Rodiah, N.S., Utomo, B.S.B., Basmal, J. \& Hastarini, E. (2016). Pemurnian Minyak Ikan Patin dari 
Hasil Samping Pengasapan Ikan. Jurnal Kelautan dan Perikanan, 11(2 ), 171-182.

Tibrani. (2015). Analisis sistem pemasaran ikan patin segar Desa Koto Masjid ke daerah tujuan pemasaran. Jurnal Dinamika Pertanian, 30(3), 273-278.

Putra, M.R. (2017). Karakteristik Mutu Ikan Patin Asap (Pangasius Sp) dengan Metode Pengasapan Tradisional dan Cair. Skripsi. Fakultas Perikanan dan Kelautan Universitas Riau 